Hydrology and Earth System Sciences, 8(4), 601-613 (2004) C EGU

\title{
Rainfall and runoff water quality of the Pang and Lambourn, tributaries of the River Thames, south-eastern England
}

\author{
Colin Neal ${ }^{1}$, Richard Skeffington ${ }^{2}$, Margaret Neal ${ }^{1}$, Roger Wyatt $^{1}$, Heather Wickham ${ }^{1}$, \\ Linda Hill ${ }^{1}$ and Ned Hewitt ${ }^{1}$
}

${ }^{1}$ Centre for Ecology and Hydrology, Wallingford, OXON, OX10 8BB, UK

${ }^{2}$ Department of Geography, Whiteknights, P.O. Box 227, Reading, RG6 2AB, UK

Email for corresponding author: cn@ceh.ac.uk

\begin{abstract}
The water quality of rainfall and runoff is described for two catchments of two tributaries of the River Thames, the Pang and Lambourn. Rainfall chemistry is variable and concentrations of most determinands decrease with increasing volume of catch probably due to 'wash out' processes. Two rainfall sites have been monitored, one for each catchment. The rainfall site on the Lambourn shows higher chemical concentrations than the one for the Pang which probably reflects higher amounts of local inputs from agricultural activity. Rainfall quality data at a long-term rainfall site on the Pang (UK National Air Quality Archive) shows chemistries similar to that for the Lambourn site, but with some clear differences. Rainfall chemistries show considerable variation on an event-to-event basis. Average water quality concentrations and flow-weighted concentrations as well as fluxes vary across the sites, typically by about $30 \%$. Stream chemistry is much less variable due to the main source of water coming from aquifer sources of high storage. The relationship between rainfall and runoff chemistry at the catchment outlet is described in terms of the relative proportions of atmospheric and within-catchment sources. Remarkably, in view of the quantity of agricultural and sewage inputs to the streams, the catchments appear to be retaining both $\mathrm{P}$ and $\mathrm{N}$.
\end{abstract}

Keywords: water quality, nitrate, ammonium, phosphorus, ammonia, nitrogen dioxide, $\mathrm{pH}$, alkalinity, nutrients, trace metals, rainfall, river, Pang, Lambourn, LOCAR

\section{Introduction}

Interest in the water quality functioning of lowland UK river systems has grown over the last ten or more years with earlier initiatives such as the Land Ocean Interaction Study (LOIS) (Leeks and Jarvie, 1998; Neal et al., 2003) and new initiatives such as LOCAR (Lowland Catchment Research: www.nerc.ac.uk/funding/thematics/locar/). Such initiatives have been undertaken to monitor the environment, understand the key processes operating and to model the dynamics of catchment systems in relation to environmental science and environmental management. The issues covered are of national and international significance within programmes such as the Land Ocean Interaction Study (LOIS), the study of European Catchments (EUROCAT), European Land Ocean Interaction Study (ELOISE), and the Land Ocean Interaction in the Coastal Zone study (LOICZ), which extend to the global level within the International Geosphere Biosphere Programme (IGBP) (Leeks and Jarvie, 1998; Cave et al., 2003).

Within the UK there is a growing emphasis on lowland river systems because the lowlands are major population and industrial centres and have the highest amount and intensity of agricultural activity; all of this leads to major issues of surface water pollution both in the context of riverine management and pollutant fluxes to the sea (Robson and Neal, 1997; Jarvie et al., 1997). Further, within lowland systems there are issues of the effects of nutrient discharges from urbanisation, industry and agriculture on biological status and riverine health as well as on the legal and environmental management options for improvement (Jarvie et al., 1998; Mainstone and Parr, 2002; Withers and Lord, 2002). 
While within the LOIS programme there was a range of interests on rural, agricultural and urban/industrial systems, there has remained until recently within the LOCAR project less emphasis on catchment research for agricultural systems. Within LOCAR, the remit is to undertake interdisciplinary programmes of integrated hydroenvironmental research relating to the input-storagedischarge cycle and in-stream, riparian and wetland habitats within groundwater-dominated systems. Key to LOCAR has been (a) the establishment of field research facilities in three contrasting permeable lowland catchments, the Frome/ Piddle in Dorset, the Pang/Lambourn in Berkshire and the Tern in Shropshire and (b) determination of the extent of these types of groundwater system throughout the UK.

This paper presents an overview on the water quality of rainfall and stream runoff from one of the main LOCAR study areas, the Pang/Lambourn, from the point of view of input-output relationships. This work is based on over a year's monitoring across the catchments and links to longer term studies by $\mathrm{CEH}$ Wallingford on examining water quality changes within the upper Thames basin (Neal et al., 2000a) at a time of climatic instability (Marsh and Sanderson, 1997). It includes water quality data for rainfall which is often overlooked in lowland catchment research but which can show up highly significant inputs (Smith et al., 1997) and it draws upon rainfall quality data from the UK National Air Quality Archive (Vincent et al., 1996). It also includes an estimate of dry deposition of some oxidised and reduced nitrogen species. This was achieved using diffusion tubes, a low-cost, well established technique for measuring gaseous concentrations of nitrogen dioxide $\left(\mathrm{NO}_{2}\right)$ and ammonia $\left(\mathrm{NH}_{3}\right)$ (Atkins et al., 1986; Sutton et al., 2001).

The paper provides a backdrop for new modelling and process based studies on the Pang/Lambourn, and complements earlier monitoring and modelling studies for the these rivers, the Kennet and main stem of the upper River Thames, into which these tributaries discharge (Neal et al., 2003).

\section{Study Area}

\section{LOCATION AND GENERAL CATCHMENT CHARACTERISTICS}

The Pang and Lambourn are tributaries of the River Thames, the principal river in south-east England. Their catchments are adjacent and their areas are about 171 and $234 \mathrm{~km}^{2}$, for the Pang and Lambourn respectively (Fig. 1). The Pang has its source towards the east of its catchment and it joins with the Thames near the town of Pangbourne. The Lambourn drains east-south-eastward from spring sources at the village of Lambourn and enters the River Kennet at Newbury, which in turn drains into the Thames near Reading to the east. Both catchments are located approximately $90 \mathrm{~km}$ from the south coast and the Thames estuary to the east. Within both catchments, land-use is largely rural to moderately intensive farming. The population is relatively low, within villages, small hamlets and farming communities in the surrounding countryside, apart from the towns of Pangbourne and Newbury at their confluence with the Thames and Kennet respectively.

The underlying geology across the area is predominantly of Cretaceous Chalk. The Pang has only one significant stream input, the Bourne, which drains clays of Eocene age while the Lambourn also has only one significant tributary input, the Winterbourne.

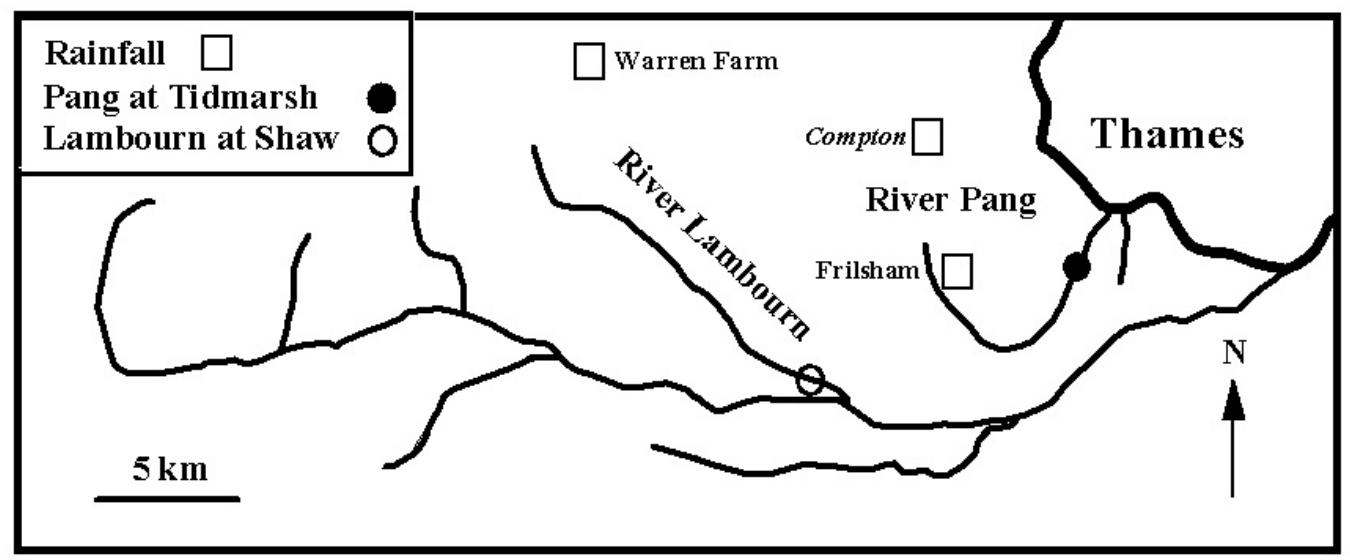

Fig. 1. Location map. The rainfall sites monitored in this study are at Warren Farm and at Frilsham. Rainfall was also monitored at Compton which links to information with the UK National Air Quality Archive, maintained by NETCEN, part of AEA Technology Environment, on behalf of the UK Department for Environment, Food \& Rural Affairs and the Devolved Administrations. The Compton site is shown in italics to denote the difference from the other two rainfall sites. 


\section{LOCATION}

This paper deals with a rainfall and a river monitoring point on each of the Pang and the Lambourn catchments (Fig. 1). While several river monitoring points have been established (Neal et al., 2000a; 2004) it is only data from the downstream sites of the Pang at Tidmarsh and the Lambourn at Shaw that are used here.

Within the Pang/Lambourn component of the LOCAR study, stream water quality monitoring began in April 2002, while rainfall water quality was measured when suitable sites were found in August 2002. For rainfall, the two rainfall collectors were of an open type and made of plastic: the funnel size was $300 \mathrm{~mm}$ diameter and small meshes were incorporated into the funnels to avoid contamination by wind-blown detritus and insects. One of the rainfall gauges is located mid-way down the Pang catchment at Frilsham Meadow and is at relatively low altitude ( $85 \mathrm{~m}$ a.s.1.). The other rainfall site is located near the top of the Lambourn catchment (200 m a.s.1.) by Warren Farm. Diffusion tube samplers for $\mathrm{NO}_{2}$ and $\mathrm{NH}_{3}$ were also located at these sites.

For the streams, the catchment and monitoring details are as follows:

\section{Pang}

During the 'pre-LOCAR phase' of the study, only the lower River Pang at Tidmarsh was studied (Neal et al., 2000a, 2004). Here, the Pang is within $3 \mathrm{~km}$ of Pangbourne and its confluence with the Thames. At Tidmarsh, the catchment has an area of about $150 \mathrm{~km}^{2}$. Monitoring began in August 1997 and is still continuing (now within the LOCAR programme).

\section{Lambourn}

This study deals with a site at Shaw within $2 \mathrm{~km}$ of its confluence with the Kennet, in the market town of Newbury. Here the catchment area is about $234 \mathrm{~km}^{2}$.

\section{SAMPLING AND ANALYSIS}

Rainfall samples were collected as weekly-integrated samples in 10 litre low density polyethylene (LDPE) containers. These samples were returned to the laboratories for filtering and chemical analysis. Stream water samples were collected weekly by 'grab sampling' and the waters were filtered in the field using $0.45 \mu \mathrm{m}$ filter circles (Whatman $47 \mathrm{~mm}$ diameter cellulose nitrate membranes). Prior to analysis, the samples were stored in glass and LDPE bottles with or without preservative depending upon specific requirements.

The details of storage and analytical methodologies were as follows:

\section{pH and gran alkalinity}

$\mathrm{pH}$ was determined by a manual method on unfiltered samples stored in $50 \mathrm{ml}$ leached glass bottles filled to the top to ensure minimum degassing of carbon dioxide (which affects pH) using a Radiometer GK2401C electrode and PHM $82 \mathrm{pH}$ meter. The system was calibrated using reference $\mathrm{pH} 4$ and 7 buffers and cross- checked against a $10^{-4} \mathrm{~N}$ and $10^{-3} \mathrm{~N}$ sulphuric acid standard. $\mathrm{pH}$ was recorded to the nearest 0.01 . Gran alkalinity was determined electrometrically by a manual method on unfiltered samples stored in $500 \mathrm{ml}$ acid washed LDPE bottles for stream waters and in $150 \mathrm{ml}$ glass bottles for rain waters using a Radiometer GK2401C electrode and PHM 82 pH meter and a two-point acidimetric titration ( $\mathrm{pH} 4$ and 3 ). The titrant acid was $0.5 \mathrm{~N}$ $\mathrm{H}_{2} \mathrm{SO}_{4}$ for stream water samples, $0.05 \mathrm{~N} \mathrm{H}_{2} \mathrm{SO}_{4}$ for rainwater samples. Gran alkalinity was recorded to the nearest $\mu \mathrm{Eq}^{-1}$. Electrical conductivity was determined by a manual method on unfiltered samples stored in $50 \mathrm{ml}$ glass bottles using a Portland Electronics Model P335 meter with values recorded to the nearest $1 \mu \mathrm{S} \mathrm{cm}^{-1}$.

Major cation and trace element concentrations ( $\mathrm{Na}, \mathrm{K}, \mathrm{Ca}$, $\mathrm{Mg}, \mathrm{Li}, \mathrm{Sr}, \mathrm{Ba}, \mathrm{Mn}, \mathrm{Co}, \mathrm{Fe}, \mathrm{Zn}, \mathrm{Cr}, \mathrm{Ni}, \mathrm{Al}$ and $\mathrm{Pb}$ )

These were determined by Inductively Coupled Plasma Optical Emission Spectroscopy using a Perkin-Elmer Optima 3300DV on filtered samples stored in $60 \mathrm{ml}$ acid washed LDPE bottles. The samples were preserved with concentrated Aristar $\mathrm{HNO}_{3}$ to $1 \% \mathrm{vv}$. Lowest quotable values for the major ions were $\mathrm{Na}, \mathrm{Mg}-0.1 \mathrm{mg} \mathrm{l}^{-1}, \mathrm{Ca}, \mathrm{K}-$ $0.05 \mathrm{mg} \mathrm{l}^{-1}$, while for the trace elements the detection limits depended on the sensitivity of the method. Li, Sr, Ba, Mn, $\mathrm{Co}-0.001 \mathrm{mg} \mathrm{l}^{-1}, \mathrm{Fe}, \mathrm{Zn}, \mathrm{Cr}, \mathrm{Ni}-0.003 \mathrm{mg} \mathrm{l}^{-1}, \mathrm{Al}, \mathrm{Pb}-$ $0.01 \mathrm{mg} \mathrm{l}^{-1}$.

\section{Major anions $\left(\mathrm{NO}_{3}, \mathrm{NO}_{2}, \mathrm{SO}_{4} \mathrm{Cl}\right.$ and $\left.\mathrm{F}\right)$}

These were determined by Ion Chromatography using a Dionex DX 500 system on filtered samples stored in $60 \mathrm{ml}$ LDPE bottles. Lowest quotable values were $\mathrm{Cl}, \mathrm{NO}_{3}$ and $\mathrm{SO}_{4}-1 \mathrm{mg} \mathrm{l}^{-1}$ (as species), $\mathrm{NO}_{2}-0.1 \mathrm{mg}-\mathrm{NO}_{2} \mathrm{l}^{-1}, \mathrm{~F}-0.05$ $\mathrm{mg} \mathrm{l}^{-1}$.

\section{Ammonium}

This was determined by automated colourimetry based on the indophenol blue method (APHA-AWWA-WPCF, 1980). The samples were stored in $60 \mathrm{ml}$. LDPE bottles prior to analysis. The lowest quotable value was $0.004 \mathrm{mg}-\mathrm{NH}_{4} \mathrm{l}^{-1}$.

\section{Silicon}

This was determined by automated colourimetry based on the method of Truesdale and Smith (1976). The samples were stored in $60 \mathrm{ml}$. LDPE bottles prior to analysis. The 
lowest quotable value was $0.1 \mathrm{mg}-\mathrm{Si}^{-1}$.

\section{Suspended sediments (SS)}

SS was determined by filtering 1 litre of sample onto a dried, weighed Whatman $47 \mathrm{~mm}$ diameter $\mathrm{GF} / \mathrm{C}$ filter paper. The filter papers were then dried in an oven, overnight, at $80{ }^{\circ} \mathrm{C}$ and reweighed on a four-figure balance. The suspended sediment was calculated by difference and the results recorded to the nearest $0.1 \mathrm{mg} \mathrm{l}^{-1}$.

\section{Phosphorus speciation}

For phosphorus, three determinations were made: soluble reactive phosphorus (SRP), a measure of inorganic monomeric P; total dissolved P (TDP), a measure of the inorganic monomeric $\mathrm{P}$, polymeric $\mathrm{P}$ and organic $\mathrm{P}$; total $\mathrm{P}$ (TP), a measure of all the dissolved forms of $\mathrm{P}$ plus particulate P. From this, the dissolved hydrolysable P (DHP), which comprises polymeric $\mathrm{P}$ and organic $\mathrm{P}$, was determined as the difference between TDP and SRP, and the particulate $\mathrm{P}$ (PP) was determined by the difference between TP and TDP. The terms SRP, DHP and PP are used in the remaining text to denote these three forms. SRP and TDP were determined on filtered samples, while TP was determined on an unfiltered sample. Separate samples were stored in $60 \mathrm{ml}$ LDPE bottles. An automated colourimetric method was employed for SRP based on the method of Murphy and Riley 1962 (see also Neal et al. 2000b). The SRP analysis was undertaken on the day of sampling to avoid degradation of samples. TDP and TP were determined manually using the method of Eisenreich et al. (1975). The samples were analysed within 3 days of sampling. Within the TDP and TP methodologies, potassium persulphate and $1 \mathrm{~N}_{2} \mathrm{SO}_{4}$ were added to the samples prior to autoclaving. The potassium persulphate was added to the samples in the field as a preservative. The lowest quotable value was $7 \mu \mathrm{g}-\mathrm{P}^{-1}$ for SRP, TDP and TP.

\section{Dissolved organic carbon (DOC) and total dissolved nitrogen (TDN)}

These were determined by thermal oxidation using an Analytical Sciences Carbon/Nitrogen Analyser. The lowest quotable values were $\mathrm{DOC}-0.1 \mathrm{mg}-\mathrm{C}^{-1} \mathrm{C}$ and $\mathrm{TN}-0.05$ $\mathrm{mg} \mathrm{l}^{-1} \mathrm{~N}$.

\section{Chlorophyll-a}

This was determined by extraction of sediment in a water sample (collected by GFC filtration) into ethanol and then a spectrophotometric measurement using a Pye Unicam SP1800 instrument (Marker, 1994). The results were recorded to the nearest $0.01 \mu \mathrm{g} \mathrm{l^{-1 }}$.

For the determination of major cations and trace metals, commercially available standards (Fisher Chemicals and BDH Spectrosol) were used for calibration. A quality control sample was run with each batch of samples immediately following the calibration and at the end of the run. Standards were also included every 10 samples to monitor for any drift. For the other analyses (major anions, $\mathrm{NH}_{4}, \mathrm{Si}$, SRP, TDP, TP, DOC and TN) the standard solutions were prepared 'in-house'. A quality control sample was run with each batch of samples immediately following the calibration and standards were also included every 10 samples to monitor for any drift. The Wallingford laboratories participate in AQUACHECK which is a UKAS accredited proficiency testing scheme, an inter-laboratory testing scheme run by the UK Acid Waters Monitoring Network and an interlaboratory testing scheme run by the Norwegian Institute for Water Research.

Passive diffusion tubes were used for the gas analysis (Atkins et al., 1986; Sutton et al., 2001). These tubes were changed every four weeks, and sent to an accredited commercial laboratory for analysis. The protocol for the $\mathrm{NO}_{2}$ tubes was that used for the UK National Network (Bush et al., 2000), that for the ammonia tubes was based on information in Sutton et al. (2001).

\section{OTHER RAINFALL DATA}

Within this study, data for a third rainfall site are presented. This is for a site in the north of the Pang catchment near the village of Compton (Fig 1). These data come from the UK National Air Quality Archive, maintained by part of AEA Technology Environment, on behalf of the UK Department for Environment, Food \& Rural Affairs and the Devolved Administrations (NETCEN): the data were kindly supplied by Helen Lawrence. These data are included as they (a) provide a longer term record than that collected under LOCAR (i.e. March 1986 up to December 2002), (b) extend the spatial coverage and (c) the site is of intermediate altitude (105 $\mathrm{m}$ a.s.1.) between the near top and near bottom of catchment sites. Information on the Compton and other sites within the UK National Air Quality Archive is described by Vincent et al. (1996) and at their web site (http:// www.aeat.co.uk/netcen/airqual/networks/cdacidnk.html).

THE ACCURACY AND MEANING OF INPUT-

OUTPUT RELATIONSHIPS: STRATEGY AND

IMPLEMENTATION

Within this paper, relations between rainfall input and river outputs are presented for water quality. Such information can be presented only as a first assessment because of several factors. 
- There is a lack of long-term data for rainfall inputs and riverine outputs.

- There is a lack of certainty over the regional groundwater routing and the catchment, given that it is permeable and is therefore not 'water tight'. Thus, there is uncertainty over the water balance (Bradford, 2002).

- The river waters drain a Chalk aquifer with residence times of the order of decades. Thus, there is no direct correspondence between the rainfall inputs measured over a particular time period, and runoff collected over the same period — the latter represents a much longer time frame.

The primary focus is to examine the data collected during the LOCAR study and compared with (a) the UK National Air Quality Archive data and (b) the longer term data record for the Pang. Clearly there are issues of comparing 'like with like' given the different monitoring periods. Initial statistical and visual time-series analysis of the concentration data revealed that for many of the water quality determinands there is no clear trend in either the rainfall or the runoff chemistry (since 1986 in the case of rainfall and since 1997 in the case of the River Pang); for simplicity, the data summaries presented here cover the full monitoring periods rather than being restricted to the period of monitoring within LOCAR.

With regard to input-output fluxes, here only inputs from the atmosphere and outputs from the river are dealt with. No direct consideration is given to issues such as the amount of fertiliser input, the uptake of chemicals by the crops, the export of harvested crops and farm animals, etc. This additional information is not available here. Within the LOCAR programme, such analysis will be undertaken within the framework, for example, of the INCA and export coefficient approaches (Johnes, 1996; Whitehead et al., 2002).

\section{Results}

\section{RAINFALL}

\section{General rainfall quality}

The rainfall at both Warren Farm and Frilsham Meadow is variable (Table 1). On occasion, the rainfall can be acidic. with $\mathrm{pH}$ as low as 4.2 and Gran alkalinities as low as -83 $\mu \mathrm{Eq}^{-1}$. However, on average, Gran alkalinities are positive, with maximum values as high as $652 \mu \mathrm{Eq}^{-1}$. The rainfall is often of 'dilute' chemistry, the major cations being $\mathrm{Na}$ and $\mathrm{Ca}$, while the major anions are $\mathrm{Cl}$ and $\mathrm{SO}_{4}$. The rainfall also contains measurable amounts of several trace metals, $\mathrm{Al}$,
$\mathrm{Fe}, \mathrm{Mn}$ and $\mathrm{Zn}$ in particular, and on rare occasions the concentrations can be particularly high: over $200 \mu \mathrm{g}^{-1}$ for $\mathrm{Al}, \mathrm{Fe}$ and $\mathrm{Mn}$, and as high as $2351 \mu \mathrm{g} \mathrm{l^{-1 }}$ for $\mathrm{Zn}$. In the case of $\mathrm{Zn}$, the top six concentrations were for Warren Farm (concentrations $>200 \mu \mathrm{g}^{-1}$ ) and of these, three had concentrations $>900 \mu \mathrm{g} \mathrm{l}^{-1}$ : thus the high concentrations cannot simply be considered as very occasional outlier points. In most cases, concentrations increase with decreasing volume of catch and this reflects (a) removal of particles in the atmosphere by rain and (b) dry deposition of particulate matter which accumulates on the rainfall collector each week. Factor analysis (with the occasional outlier values removed for the trace metals) reveals two main groupings for both Frilsham Meadow and Warren Farm and an extra group for Warren Farm:

- The first group describes about 35 and $45 \%$ of the total variance for Frilsham Meadow and Warren Farm, respectively. It comprises electrical conductivity (EC), SRP, DHP, PP, $\mathrm{NH}_{4}, \mathrm{~F}, \mathrm{NO}_{2}, \mathrm{NO}_{3}, \mathrm{SO}_{4}$, total dissolved nitrogen (TDN), organic nitrogen, $\mathrm{Si}, \mathrm{K}, \mathrm{Ca}, \mathrm{B}, \mathrm{Sr}, \mathrm{Ba}$, $\mathrm{Zn}, \mathrm{Cu}, \mathrm{Cr}$ and $\mathrm{Al}$. This group also includes a negative relationship with volume of catch. Many of these components are probably derived in significant part from local sources.

- The second group accounts for about 16 and $10 \%$ of the variance for Frilsham Meadow and Warren Farm, respectively. It comprises $\mathrm{Na}, \mathrm{Cl}$ and $\mathrm{Mg}$. This group corresponds to atmospheric inputs of 'sea salts'. For this group, there is an extremely strong linear correlation with intercepts not statistically significant from zero $(p<0.001)$ as would be expected given the low lithogenic sources. These regressions are (in $\mathrm{mg} \mathrm{l}^{-1}$ units: the \pm tem refers to two standard deviations):

o $\quad \mathrm{Na}=0.566 \pm 0.012 * \mathrm{Cl}+0.04 \pm 0.39: \mathrm{r}^{2}=0.994, \mathrm{~N}=36$.

o $\mathrm{Mg}=0.0685 \pm 0.0082 * \mathrm{Cl}+0.06 \pm 0.22: \mathrm{r}^{2}=0.891, \mathrm{~N}=36$.

- In addition to the above two groupings, there is a strong third grouping for Warren Farm which accounts for about $15 \%$ of the variance. This grouping comprises $\mathrm{Li}, \mathrm{Mn}, \mathrm{Co}$ and $\mathrm{Ni}$ in negative relation with most of the first group; it is weakly linked to volume of catch. These inputs will be associated with local pollutant sources.

In terms of the relative input of the sea salts, the main chemical determinands involved are $\mathrm{Na}, \mathrm{Cl}, \mathrm{K}, \mathrm{Mg}, \mathrm{B}$ and Sr. To examine the relative input of 'non sea salt components', a comparison is made between ratios of the components to chloride for the rainfall $\left(\mathrm{R}_{\text {rain }}\right)$ and for seawater $\left(R_{S W}\right)\left(R_{\text {rain:sw }}\right.$; Table 2$)$. This analysis reveals four categories. 
Table 1. Rainfall statistics for Warren Farm and Frilsham Meadow.

\begin{tabular}{|c|c|c|c|c|c|c|c|c|c|}
\hline & & Average & $\begin{array}{l}\text { FRILSHAM } \\
\text { Average } \\
\text { Catch } \\
\text { weighted }\end{array}$ & Min. & Max. & Average & $\begin{array}{l}\text { WARREN } \\
\text { Average } \\
\text { Catch } \\
\text { weighted }\end{array}$ & Min. & Max. \\
\hline $\mathrm{EC}$ & $\mu \mathrm{Scm}^{-1}$ & 34.1 & 24.3 & 11.0 & 121 & 62.9 & 40.4 & 16.0 & 150.0 \\
\hline $\mathrm{pH}$ & & 5.75 & 5.64 & 4.20 & 6.68 & 6.50 & 6.26 & 4.94 & 7.32 \\
\hline ALK & $\mu \mathrm{Eql}^{-1}$ & 4 & -1 & -83 & 124 & 107 & 55 & -53 & 652 \\
\hline $\mathrm{Na}$ & $\mathrm{mg} \mathrm{l}^{-1}$ & 2.67 & 1.62 & 0.20 & 15.6 & 5.03 & 2.25 & 0.32 & 19.1 \\
\hline K & $\mathrm{mg} \mathrm{l}^{-1}$ & 0.28 & 0.13 & 0.04 & 0.99 & 0.53 & 0.23 & 0.06 & 2.44 \\
\hline $\mathrm{Ca}$ & $\mathrm{mg} \mathrm{l}^{-1}$ & 2.31 & 0.72 & 0.14 & 12.7 & 4.27 & 2.07 & 0.39 & 29.7 \\
\hline $\mathrm{Mg}$ & $\mathrm{mg} \mathrm{l}^{-1}$ & 0.39 & 0.22 & 0.06 & 1.91 & 0.74 & 0.33 & 0.08 & 2.30 \\
\hline $\mathrm{Cl}$ & $\mathrm{mg} \mathrm{l}^{-1}$ & 6.42 & 2.89 & 0.00 & 35.00 & 9.43 & 3.87 & 0.00 & 65.0 \\
\hline $\mathrm{SO}_{4}$ & $\mathrm{mg} \mathrm{l}^{-1}$ & 6.55 & 2.05 & 0.00 & 72.5 & 10.0 & 3.03 & 0.00 & 112.5 \\
\hline $\mathrm{F}$ & $\mathrm{mg} \mathrm{l}^{-1}$ & 0.06 & 0.01 & 0.00 & 1.05 & 0.07 & 0.01 & 0.00 & 0.80 \\
\hline $\mathrm{NO}_{3}$ & $\mathrm{mg} \mathrm{l}^{-1} \mathrm{~N}$ & 2.11 & 0.39 & 0.00 & 42.9 & 2.28 & 0.61 & 0.00 & 16.4 \\
\hline $\mathrm{NO}_{2}$ & $\mathrm{mg} \mathrm{l}^{-1} \mathrm{~N}$ & 0.04 & 0.00 & 0.00 & 0.67 & 0.05 & 0.01 & 0.00 & 0.61 \\
\hline $\mathrm{NH}_{4}$ & $\mathrm{mg} \mathrm{l}^{-1} \mathrm{~N}$ & 1.53 & 0.49 & 0.04 & 13.7 & 1.98 & 0.83 & 0.26 & 9.33 \\
\hline TDN & $\mathrm{mg} \mathrm{l}^{-1} \mathrm{~N}$ & 4.94 & 1.12 & 0.40 & 85.0 & 5.88 & 1.96 & 0.40 & 35.7 \\
\hline InorgN & $\mathrm{mg} \mathrm{l}^{-1} \mathrm{~N}$ & 3.68 & 0.88 & 0.04 & 57.26 & 4.31 & 1.45 & 0.26 & 26.31 \\
\hline Org N & $\mathrm{mg} \mathrm{l}^{-1} \mathrm{~N}$ & 1.26 & 0.24 & 0.36 & 27.74 & 1.57 & 0.51 & 0.14 & 9.39 \\
\hline SRP & $\mu \mathrm{g} \mathrm{l}^{-1} \mathrm{P}$ & 68.4 & 10.7 & 0.0 & 1794 & 139.5 & 56.1 & 0.0 & 1126 \\
\hline DHP & $\mu \mathrm{g} \mathrm{l}^{-1} \mathrm{P}$ & 20.5 & 4.3 & 0.0 & 346 & 54.5 & 11.7 & 0.0 & 883 \\
\hline PP & $\mu \mathrm{g} \mathrm{l}^{-1} \mathrm{P}$ & 36.8 & 11.9 & 0.0 & 220 & 79.8 & 30.1 & 0.0 & 1268 \\
\hline DOC & $\mathrm{mg} \mathrm{l}^{-1} \mathrm{C}$ & 3.87 & 1.63 & 0.30 & 19.50 & 5.01 & 2.00 & 0.50 & 24.00 \\
\hline $\mathrm{Si}$ & $\mathrm{mg}^{-1} \mathrm{Si}$ & 0.02 & 0.00 & 0.00 & 0.30 & 0.03 & 0.01 & 0.00 & 0.30 \\
\hline $\mathrm{Al}$ & $\mu g 1^{-1}$ & 11.8 & 7.8 & 0.0 & 87.7 & 20.2 & 8.9 & 0.0 & 224 \\
\hline B & $\mu \mathrm{g} \mathrm{l}^{-1}$ & 2.8 & 1.2 & 0.0 & 12.1 & & 3.7 & 1.5 & 0.0 \\
\hline \multicolumn{10}{|l|}{20.7} \\
\hline $\mathrm{Ba}$ & $\mu \mathrm{g}^{-1}$ & 4.2 & 2.1 & 0.4 & 12.0 & 3.8 & 2.3 & 0.6 & 15.1 \\
\hline Co & $\mu \mathrm{g} \mathrm{l}^{-1}$ & 0.2 & 0.2 & 0.0 & 0.8 & 2.9 & 0.9 & 0.0 & 116 \\
\hline $\mathrm{Cr}$ & $\mu \mathrm{g} \mathrm{l}^{-1}$ & 0.3 & 0.2 & 0.0 & 0.8 & 1.8 & 0.7 & 0.0 & 59.9 \\
\hline $\mathrm{Cu}$ & $\mu \mathrm{g} \mathrm{l}^{-1}$ & 2.6 & 0.9 & 0.0 & 10.9 & 2.3 & 0.7 & 0.0 & 13.0 \\
\hline $\mathrm{Fe}$ & $\mu \mathrm{g} \mathrm{l}^{-1}$ & 13.4 & 10.4 & 2.6 & 99 & 24.6 & 11.9 & 1.6 & 500 \\
\hline $\mathrm{Li}$ & $\mu \mathrm{g} \mathrm{l}^{-1}$ & 1.7 & 1.6 & 0.0 & 7.1 & 1.2 & 1.1 & 0.0 & 5.8 \\
\hline $\mathrm{Mn}$ & $\mu \mathrm{g} \mathrm{l}^{-1}$ & 15.5 & 6.7 & 1.0 & 109 & 11.8 & 6.6 & 1.1 & 124 \\
\hline Mo & $\mu \mathrm{g} \mathrm{l}^{-1}$ & 2.1 & 1.9 & 0.0 & 14.0 & 2.6 & 2.3 & 0.0 & 14.3 \\
\hline $\mathrm{Ni}$ & $\mu \mathrm{g} \mathrm{1^{-1 }}$ & 2.7 & 2.0 & 0.0 & 23.2 & 5.4 & 2.3 & 0.0 & 38.8 \\
\hline $\mathrm{Pb}$ & $\mu \mathrm{g} \mathrm{l}^{-1}$ & 1.2 & 1.39 & 0.00 & 4.83 & 1.2 & 1.0 & 0.0 & 11.0 \\
\hline $\mathrm{Sr}$ & $\mu \mathrm{g} \mathrm{l}^{-1}$ & 6.5 & 2.6 & 0.5 & 34.0 & 9.9 & 4.9 & 1.1 & 50.4 \\
\hline $\mathrm{Zn}$ & $\mu \mathrm{g}^{-1}$ & 42.2 & 36.1 & 7.1 & 131 & 204 & 141 & 3.5 & 2351 \\
\hline
\end{tabular}


Table 2. Element ratios to chloride for rainfall $\left(\mathrm{R}_{\text {rain }}\right)$, including a comparison with sea water ratios $\left(\mathrm{R}_{\text {rain:Sw }}\right)$. The ratios for sea water are provided by data in Drever (2002). Rainfall data refer to catch-weighted averages (analysis for straight-averages gives very similar results).

\begin{tabular}{|c|c|c|c|c|c|c|}
\hline & & \multirow{2}{*}{$\begin{array}{l}\text { SEA WATER } \\
R_{S W}\end{array}$} & \multicolumn{2}{|c|}{ FRILSHAM MEADOW } & \multicolumn{2}{|c|}{ WARREN FARM } \\
\hline & & & $R_{\text {rain }}$ & $R_{\text {rain:SW }}$ & $R_{\text {rain }}$ & $R_{\text {rain:SW }}$ \\
\hline $\mathrm{Na} / \mathrm{Cl}$ & $\mathrm{mg}: \mathrm{mg}$ & 0.556 & 0.561 & 1.01 & 0.561 & 1.01 \\
\hline $\mathrm{K} / \mathrm{Cl}$ & $\mathrm{mg}: \mathrm{mg}$ & 0.021 & 0.042 & 2.05 & 0.059 & 2.81 \\
\hline $\mathrm{Ca} / \mathrm{Cl}$ & $\mathrm{mg}: \mathrm{mg}$ & 0.021 & 0.365 & 17.2 & 0.512 & 24.0 \\
\hline $\mathrm{Mg} / \mathrm{Cl}$ & $\mathrm{mg}: \mathrm{mg}$ & 0.067 & 0.058 & 0.87 & 0.084 & 1.26 \\
\hline $\mathrm{SO}_{4} / \mathrm{Cl}$ & $\mathrm{Mg}-\mathrm{SO}_{4}: \mathrm{mg}$ & 0.140 & 1.190 & 8.50 & 1.183 & 8.45 \\
\hline $\mathrm{B} / \mathrm{Cl}$ & $\mu \mathrm{g}: \mathrm{mg}$ & 0.233 & 0.440 & 1.89 & 0.228 & 0.98 \\
\hline $\mathrm{Sr} / \mathrm{Cl}$ & $\mu \mathrm{g}: \mathrm{mg}$ & 0.413 & 1.022 & 2.47 & 0.750 & 1.81 \\
\hline
\end{tabular}

1. There are components where $\mathrm{R}_{\text {rain:SW }}$ is close to unity. These components are the main 'sea salts' $\mathrm{Na}, \mathrm{Cl}$ and $\mathrm{Mg}$.

2. There are components with $\mathrm{R}_{\text {rain:sw }}$ about two to four times that for seawater. These components are K, B and $\mathrm{Sr}$ and they have approximately an equal mix of marine and non-marine sources.

3. There is a group comprising $\mathrm{Ca}$ and $\mathrm{SO}_{4}$ where clearly there are major non-marine sources $\left(\mathrm{R}_{\text {rain:SW }} 8\right.$ to 24$)$.

4. For the other determinands, the trace metals in particular, the non-marine inputs dominate $\left(\mathrm{R}_{\text {rain:SW }}>30\right)$.

\section{WARREN FARM - FRILSHAM MEADOW}

\section{COMPARISONS}

The concentrations of the major elements are linearly correlated for most water quality determinands between the two sites. Linear correlation analysis (excluding occasional outlier values) indicates highly significant correlations $(\mathrm{p}<0.002)$ for the sea salts $(\mathrm{Na}, \mathrm{Cl}$ and $\mathrm{Mg})$, electrical conductivity, Gran alkalinity, $\mathrm{B}, \mathrm{Co}, \mathrm{Cu}, \mathrm{Cr}, \mathrm{Ba}, \mathrm{Ca}, \mathrm{Cl}, \mathrm{F}$, $\mathrm{K}, \mathrm{Pb}, \mathrm{pH}, \mathrm{Mn}, \mathrm{Mo}, \mathrm{Ni}, \mathrm{NH}_{4}, \mathrm{NO}_{3}, \mathrm{TN}, \mathrm{DHP}, \mathrm{PP}, \mathrm{Si}, \mathrm{Sr}$, $\mathrm{SO}_{4}$, and $\mathrm{Zn}$. Poorer correlations occur for $\mathrm{Al}, \mathrm{Li}, \mathrm{Fe}, \mathrm{NO}_{2}$, SRP, DHP and PP. The concentrations for most chemical determinands are higher for Warren Farm compared with Frilsham Meadow (Table 3) and on average the enrichment is of the order of a factor of two. The enrichment factors are greatest for SRP and Cr (enrichment factors of 4 to 9), followed by $\mathrm{Zn}, \mathrm{Cu}, \mathrm{Ca}, \mathrm{DHP}$ and PP (enrichment factors of 2 to 4 ) and then by $\mathrm{Na}, \mathrm{Cl}, \mathrm{B}, \mathrm{Sr}, \mathrm{K}, \mathrm{NH}_{4}, \mathrm{NO}_{3}, \mathrm{Mg}$ and $\mathrm{SO}_{4}$ (enrichment factors of 1.2 to 2 ).

With regard to the rainfall at the two sites, the volumes of catch, in $\mathrm{ml}$, are highly correlated:

$$
\begin{aligned}
& \text { Rainfall }_{\text {Frilsham }}=0.88 \pm 0.06 * \text { Rainfall }_{\text {Warren Farm }}+56 \pm 615 \\
& \mathrm{~N}=46, \mathrm{R}^{2}=0.952 .
\end{aligned}
$$

On average, the rainfall catch at Frilsham is about $8 \%$ lower than that at Warren Farm; this compares well with long term averages of rainfall for the two catchments (IH, 1998) where the Pang catchment has an estimated rainfall input about 5\% lower than that of the Lambourn.

The concentrations of many determinands are inversely related to the volume of catch at each site and there is bound to be some correlation of concentrations and indeed of fluxes as volumes are strongly correlated. N.B. here correlation expressions are used, not regression calculations regression assumes a dependent and an independent variable, which is not the case with this dataset.

In terms of chemical flux, then the higher concentrations at Warren farm coupled with a (slightly) higher volume of catch than Frilsham, indicates a higher flux term for the Lambourn for many determinands.

\section{WARREN FARM - FRILSHAM MEADOW - COMPTON COMPARISONS}

There is also a systematic difference between the water quality of the Compton site and that of Frilsham Meadow and Compton site has water quality nearer to that for Warren Farm (Table 3). Taking the average volume of catch weighted concentration for each determinand across the three sites and comparing values with those for each site and each determinand shows that:

- Frilsham Meadow has average concentrations for the various determinands between 0.14 and 0.8 times that for the area-average (average 0.6).

- Warren Farm and Compton have average concentrations for the various determinands between 0.84 and 1.64 times that for the average across the sites (average 1.11 and 1.29 , respectively).

- There are some marked differences for some 
Table 3. A comparison of volume weighted water quality averages for rainfall at Frilsham, Warren Farm and Compton. The "average all" column refers to the mean volume weighted concentration for each determinand at Frilsham, Warren Farm and Compton. The ratio of averages is the ratio of the average volume-weighted concentration at a particular site divided by the average for all three sites. The units

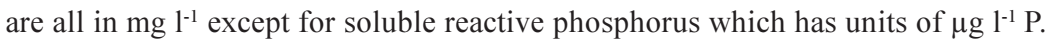

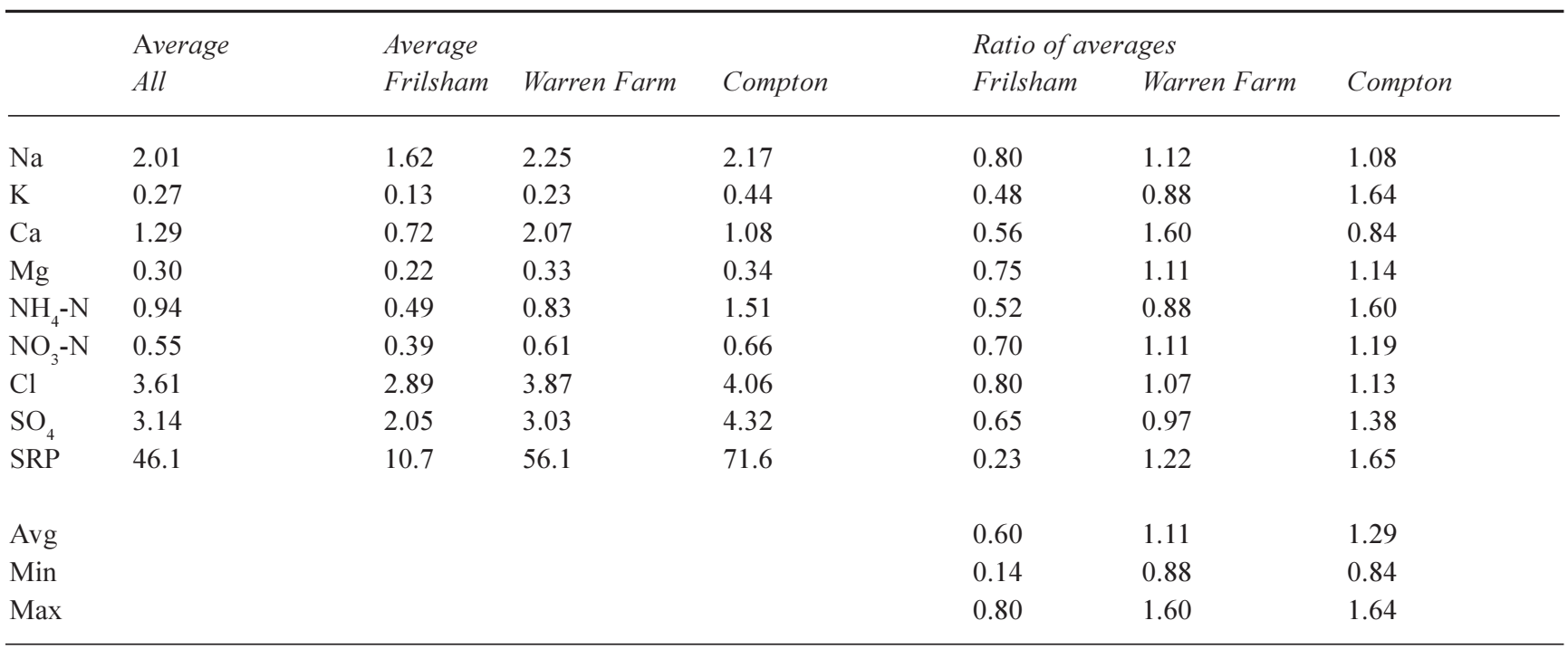

determinands for the Warren Farm and Compton sites. In particular, enrichments are higher at Warren Farm for $\mathrm{Ca}$ and enrichments are higher at Compton for $\mathrm{K}$, $\mathrm{NH}_{4}, \mathrm{SO}_{4}$ and SRP. These enrichments are up to a factor of about 2 .

\section{RIVER WATER CHEMISTRY}

The river water quality corresponds to that typical for Chalk fed aquifers (Owen et al., 1991) except that the stream waters have higher $\mathrm{pHs}$ due to degassing of carbon dioxide (Neal et al., 2002b). Thus, the waters are calcium- and bicarbonate bearing and have relatively uniform concentrations. Agricultural inputs may well result in enhanced levels of nutrients, nitrate, SRP and PP in particular but other factors come into play (Neal et al., 2004). For nitrate, the concentrations are higher during the winter months due to a combination of increased surface runoff with higher $\mathrm{NO}_{3}$ sources from fertilisers, and less biological uptake. Point source inputs (sewage treatment works effluent) result in enhanced concentrations of several major ions as well as B. A detailed description of the water quality of the Pang and Lambourn can be found in Neal et al. (2000a, 2004). In general, the Pang and the Lambourn have very similar water quality, with only relatively minor variations in average and ranges in chemistry (Table 4): the differences in chemistry are discussed by Neal et al. (2004).

\section{RAINFALL - RUNOFF RELATIONSHIPS}

Because of the variation in rainfall chemistry across the Pang and Lambourn, it is not possible to obtain a truly accurate measurement of the wet deposition input of chemicals to either of the catchments. For the present purposes, the fluxes are calculated using the Frilsham Meadow and Warren Farm as measures of the wet input from the Pang and Lambourn, respectively. For the streams, the flow weighted average concentrations were used. For the estimation of wet-input output relationships, the flow weighted concentrations were multiplied by the long term averages for rainfall and river flow for the two catchments. These long term averages are taken from the Hydrological data for the UK (IH, 1998): for the Pang, rainfall $702 \mathrm{~mm}$, runoff $162 \mathrm{~mm}$; for the Lambourn, rainfall $739 \mathrm{~mm}$, runoff $231 \mathrm{~mm}$. The results of this exercise are shown in Table 5. There are very wide ranges of atmospheric input- riverine output relationships. Clearly the catchment balances will be influenced by the size of the flux involved as for example the net riverine output-atmospheric input fluxes will often be smaller for the trace elements compared to the majors. An estimate of source in runoff from the catchment is taken as the ratio of the net flux to the river flux, expressed as a percentage $(\% \mathrm{C}$ $=100 *$ (riverine output-atmospheric input)/riverine output), but large negative values can occur when the atmospheric input flux is particularly high. The relationships are very similar for both the catchments and the salient details are as follows.

- A net riverine export relative to the atmospheric input 
Table 4. Pang and Lambourn water quality statistics

\begin{tabular}{|c|c|c|c|c|c|c|c|c|c|}
\hline & & & PANG: & MARSH & & & LAMBOL & : SHAW & \\
\hline & & $A v g$ & $A v g f w$ & Min & $\operatorname{Max}$ & $A v g$ & Avgfw & Min & $\operatorname{Max}$ \\
\hline $\mathrm{EC}$ & $\mu \mathrm{Scm}^{-1}$ & 618 & 627 & 460 & 674 & 593 & 596 & 554 & 627 \\
\hline $\mathrm{pH}$ & & 7.91 & 7.87 & 7.57 & 8.18 & 7.91 & 7.90 & 7.47 & 8.15 \\
\hline ALK & $\mu \mathrm{Eq} / 1$ & 4732 & 4786 & 2752 & 5265 & 4702 & 4681 & 4249 & 4947 \\
\hline $\mathrm{Na}$ & $\mathrm{mg} \mathrm{l}^{-1}$ & 11.1 & 11.5 & 9.4 & 13.7 & 9.20 & 9.29 & 8.53 & 10.87 \\
\hline K & $\mathrm{mg} \mathrm{l}^{-1}$ & 3.01 & 3.00 & 1.92 & 6.99 & 1.86 & 1.85 & 1.38 & 4.70 \\
\hline $\mathrm{Ca}$ & $\mathrm{mg} \mathrm{l}^{-1}$ & 108.7 & 109.9 & 69.3 & 119.0 & 109.0 & 109.0 & 92.0 & 113.2 \\
\hline $\mathrm{Mg}$ & $\mathrm{mg} \mathrm{l}^{-1}$ & 3.05 & 3.01 & 2.1 & 4.57 & 1.77 & 1.77 & 1.66 & 1.85 \\
\hline $\mathrm{Cl}$ & $\mathrm{mg} \mathrm{l}^{-1}$ & 22.5 & 23.0 & 18.0 & 26.5 & 18.1 & 18.6 & 15.0 & 22.5 \\
\hline $\mathrm{SO}_{4}$ & $\mathrm{mg} \mathrm{l}^{-1}$ & 20.0 & 20.0 & 16.0 & 32.0 & 13.9 & 14.8 & 12.0 & 18.5 \\
\hline $\mathrm{F}$ & $\mathrm{mg} \mathrm{l}^{-1}$ & 0.17 & 0.19 & 0.12 & 0.24 & 0.14 & 0.14 & 0.11 & 0.19 \\
\hline $\mathrm{NO}_{3}$ & $\mathrm{mg} \mathrm{l}^{-1} \mathrm{~N}$ & 7.09 & 7.58 & 4.52 & 8.92 & 6.94 & 7.27 & 5.42 & 8.58 \\
\hline $\mathrm{NO}_{2}$ & $\mathrm{mg} \mathrm{l}^{-1} \mathrm{~N}$ & 0.06 & 0.07 & 0.00 & 0.15 & 0.04 & 0.04 & 0.00 & 0.15 \\
\hline $\mathrm{NH}_{4}$ & $\mathrm{mg} \mathrm{l}^{-1} \mathrm{~N}$ & 0.03 & 0.04 & 0.00 & 0.08 & 0.05 & 0.04 & 0.01 & 0.14 \\
\hline $\mathrm{TN}$ & $\mathrm{mg} \mathrm{l}^{-1} \mathrm{~N}$ & 7.88 & 8.36 & 6.20 & 10.30 & 7.64 & 7.92 & 6.70 & 9.50 \\
\hline Inorg N & $\mathrm{mg} \mathrm{l}^{-1} \mathrm{~N}$ & 7.19 & 7.69 & 4.52 & 9.15 & 7.03 & 7.35 & 5.43 & 8.88 \\
\hline Org N & $\mathrm{mg} \mathrm{l}^{-1} \mathrm{~N}$ & 0.69 & 0.67 & 1.68 & 1.15 & 0.62 & 0.57 & 1.27 & 0.62 \\
\hline SRP & $\mu \mathrm{g}^{-1} \mathrm{P}$ & 47 & 57 & 7 & 134 & 97 & 94 & 55 & 228 \\
\hline DHP & $\mu \mathrm{g}^{-1} \mathrm{P}$ & 13 & 14 & 0 & 15 & 15 & 14 & 17 & 5 \\
\hline PP & $\mu \mathrm{g}^{-1} \mathrm{P}$ & 17 & 19 & 0 & 128 & 14 & 14 & 13 & 36 \\
\hline DOC & $\mathrm{mg} \mathrm{l}^{-1} \mathrm{C}$ & 2.10 & 2.27 & 0.80 & 8.30 & 1.54 & 1.48 & 0.70 & 6.20 \\
\hline $\mathrm{Si}$ & $\mathrm{mg} \mathrm{l}^{-1} \mathrm{Si}$ & 6.92 & 6.84 & 4.60 & 8.00 & 6.91 & 6.82 & 5.90 & 7.50 \\
\hline $\mathrm{Al}$ & $\mu \mathrm{g} \mathrm{l}^{-1}$ & 10.0 & 13.3 & 0.0 & 165.9 & 9.4 & 10.3 & 0.0 & 40.0 \\
\hline B & $\mu \mathrm{g} \mathrm{l}^{-1}$ & 21.0 & 21.4 & 10.0 & 35.1 & 18.9 & 19.0 & 14.8 & 23.4 \\
\hline $\mathrm{Ba}$ & $\mu \mathrm{g} \mathrm{l}^{-1}$ & 28.8 & 28.8 & 21.0 & 32.6 & 19.4 & 18.8 & 16.2 & 24.4 \\
\hline Co & $\mu \mathrm{g} \mathrm{l}^{-1}$ & 0.2 & 0.2 & 0.0 & 1.1 & 0.2 & 0.2 & 0.0 & 1.5 \\
\hline $\mathrm{Cr}$ & $\mu \mathrm{g} \mathrm{l}^{-1}$ & 0.2 & 0.1 & 0.0 & 0.7 & 0.1 & 0.1 & 0.0 & 0.6 \\
\hline $\mathrm{Fe}$ & $\mu \mathrm{g} \mathrm{l}^{-1}$ & 20.4 & 25.3 & 4.0 & 197.1 & 10.2 & 9.3 & 3.7 & 30.6 \\
\hline $\mathrm{Mn}$ & $\mu \mathrm{g} \mathrm{l}^{-1}$ & 3.3 & 4.1 & 1.0 & 8.5 & 3.1 & 3.0 & 1.7 & 7.0 \\
\hline $\mathrm{Ni}$ & $\mu \mathrm{g} \mathrm{l}^{-1}$ & 2.8 & 3.1 & 0.0 & 4.4 & 2.1 & 2.2 & 0.0 & 4.4 \\
\hline $\mathrm{Sr}$ & $\mu \mathrm{g} \mathrm{l}^{-1}$ & 309 & 300 & 192 & 352 & 257 & 255 & 207 & 278 \\
\hline $\mathrm{Zn}$ & $\mu \mathrm{g} \mathrm{l}^{-1}$ & 23.9 & 28.2 & 0.0 & 129.2 & 16.2 & 17.6 & 0.2 & 41.1 \\
\hline
\end{tabular}

with predominantly catchment sources. These are the major weathering products from the catchment: $\mathrm{Ca}, \mathrm{Sr}$, Alkalinity (bicarbonate) from calcite dissolution and $\mathrm{Si}$ from silicate breakdown.

- A net riverine export relative to the atmospheric input with significant within catchment sources. These include weathering products ( $\mathrm{Mg}, \mathrm{Ba}, \mathrm{F})$, components associated with agricultural practices $\left(\mathrm{Ba}, \mathrm{NO}_{2}\right)$ including fertilizer application $\left(\mathrm{NO}_{2}, \mathrm{NO}_{3}, \mathrm{~K}\right.$, total $\left.\mathrm{N}\right)$ and point source inputs (B).

- A net riverine export relative to the atmospheric input with significant atmospheric inputs. This group comprises $\mathrm{Na}, \mathrm{Cl}$, inorganic/total $\mathrm{N}$, and $\mathrm{SO}_{4}$.

- A net retention of the atmospheric inputs relative to the riverine outputs. These comprise components with a highly significant atmospheric input with loss to the 
Table 5. Pang and Lambourn wet-deposition-input output relationships. All concentrations in elemental terms except sulphate and alkalinity.

\begin{tabular}{|c|c|c|c|c|c|c|c|c|c|}
\hline & & Rain & $\begin{array}{l}\text { PANG } \\
\text { River }\end{array}$ & Net flux & $\begin{array}{l}\% \text { catch. } \\
\text { source }\end{array}$ & Rain & $\begin{array}{l}\text { Lambour } \\
\text { River }\end{array}$ & Netflux & $\begin{array}{l}\% \text { catch. } \\
\text { source }\end{array}$ \\
\hline Alk & eq $\mathrm{ha}^{-1} \mathrm{yr}^{-1}$ & -9 & 5456 & 5466 & 100 & 406 & 10811 & 10405 & 96 \\
\hline $\mathrm{Na}$ & $\mathrm{kg} \mathrm{ha}^{-1} \mathrm{yr}^{-1}$ & 11.34 & 13.05 & 1.71 & 13 & 14.29 & 21.46 & 7.17 & 33 \\
\hline K & $\mathrm{kg} \mathrm{ha}^{-1} \mathrm{yr}^{-1}$ & 0.89 & 3.42 & 2.54 & 74 & 1.33 & 4.27 & 2.94 & 69 \\
\hline $\mathrm{Ca}$ & $\mathrm{kg} \mathrm{ha}^{-1} \mathrm{yr}^{-1}$ & 5.05 & 125.27 & 120.21 & 96 & 10.31 & 251.85 & 241.55 & 96 \\
\hline $\mathrm{Mg}$ & $\mathrm{kg} \mathrm{ha}^{-1} \mathrm{yr}^{-1}$ & 1.57 & 3.43 & 1.87 & 54 & 2.03 & 4.09 & 2.05 & 50 \\
\hline $\mathrm{Cl}$ & $\mathrm{kg} \mathrm{ha}^{-1} \mathrm{yr}^{-1}$ & 20.31 & 26.20 & 5.89 & 22 & 24.98 & 42.88 & 17.90 & 42 \\
\hline $\mathrm{SO}_{4}$ & $\mathrm{~kg} \mathrm{ha}^{-1} \mathrm{yr}^{-1}$ & 14.40 & 22.74 & 8.35 & 37 & 18.79 & 34.14 & 15.36 & 45 \\
\hline $\mathrm{F}$ & $\mathrm{kg} \mathrm{ha}^{-1} \mathrm{yr}^{-1}$ & 0.05 & 0.22 & 0.17 & 77 & 0.07 & 0.32 & 0.25 & 79 \\
\hline $\mathrm{NO}_{3}-\mathrm{N}$ & $\mathrm{kg} \mathrm{ha}^{-1} \mathrm{yr}^{-1}$ & 2.71 & 8.65 & 5.93 & 69 & 3.69 & 16.78 & 13.09 & 78 \\
\hline $\mathrm{NO}_{2}-\mathrm{N}$ & $\mathrm{kg} \mathrm{ha}^{-1} \mathrm{yr}^{-1}$ & 0.02 & 0.08 & 0.05 & 70 & 0.04 & 0.10 & 0.05 & 53 \\
\hline $\mathrm{NH}_{4}-\mathrm{N}$ & $\mathrm{kg} \mathrm{ha}^{-1} \mathrm{yr}^{-1}$ & 3.42 & 0.04 & -3.38 & -8154 & 4.86 & 0.10 & -4.76 & -4832 \\
\hline $\mathrm{TN}$ & $\mathrm{kg} \mathrm{ha}^{-1} \mathrm{yr}^{-1}$ & 7.86 & 9.53 & 1.67 & 18 & 11.36 & 18.30 & 6.93 & 38 \\
\hline Inorg $\mathrm{N}$ & $\mathrm{kg} \mathrm{ha}^{-1} \mathrm{yr}^{-1}$ & 6.15 & 8.76 & 2.61 & 30 & 8.60 & 16.97 & 8.38 & 49 \\
\hline Org N & $\mathrm{kg} \mathrm{ha}^{-1} \mathrm{yr}^{-1}$ & 1.70 & 0.76 & -0.94 & -123 & 2.76 & 1.32 & -1.44 & -109 \\
\hline SRP & $\mathrm{g} \mathrm{ha}^{-1} \mathrm{yr}^{-1}$ & 74.97 & 65.44 & -9.53 & -15 & 231.04 & 216.38 & -14.66 & -7 \\
\hline DHP & $\mathrm{g} \mathrm{ha}^{-1} \mathrm{yr}^{-1}$ & 30.13 & 15.93 & -14.20 & -47 & 48.18 & 31.96 & -16.22 & -51 \\
\hline PP & $\mathrm{g} \mathrm{ha}^{-1} \mathrm{yr}^{-1}$ & 83.39 & 21.92 & -61.46 & -280 & 123.96 & 32.96 & -91.00 & -276 \\
\hline $\mathrm{TP}$ & $\mathrm{g} \mathrm{ha}^{-1} \mathrm{yr}^{-1}$ & 188.49 & 103.29 & -85.20 & -82 & 403.18 & 281.30 & -121.88 & -433 \\
\hline DOC & $\mathrm{kg} \mathrm{ha}^{-1} \mathrm{yr}^{-1}$ & 11.44 & 2.59 & -8.85 & -342 & 13.40 & 3.42 & -9.98 & -292 \\
\hline $\mathrm{Si}$ & $\mathrm{kg} \mathrm{ha}^{-1} \mathrm{yr}^{-1}$ & 0.02 & 7.80 & 7.78 & 100 & 0.04 & 15.76 & 15.73 & 100 \\
\hline $\mathrm{Al}$ & $\mathrm{g} \mathrm{ha}^{-1} \mathrm{yr}^{-1}$ & 54.71 & 15.20 & -39.52 & -260 & 61.68 & 18.51 & -43.17 & -233 \\
\hline B & $\mathrm{g} \mathrm{ha}^{-1} \mathrm{yr}^{-1}$ & 8.57 & 24.36 & 15.79 & 65 & 10.04 & 43.81 & 33.77 & 77 \\
\hline $\mathrm{Ba}$ & $\mathrm{g} \mathrm{ha}^{-1} \mathrm{yr}^{-1}$ & 14.77 & 32.85 & 18.08 & 55 & 16.27 & 43.44 & 27.17 & 63 \\
\hline Co & $\mathrm{g} \mathrm{ha}^{-1} \mathrm{yr}^{-1}$ & 1.47 & 0.22 & -1.25 & -576 & 4.12 & 0.35 & -3.77 & -1075 \\
\hline $\mathrm{Cr}$ & $\mathrm{g} \mathrm{ha}^{-1} \mathrm{yr}^{-1}$ & 1.70 & 0.13 & -1.57 & -1177 & 3.60 & 0.17 & -3.43 & -2044 \\
\hline $\mathrm{Fe}$ & $\mathrm{g} \mathrm{ha}^{-1} \mathrm{yr}^{-1}$ & 73.01 & 28.81 & -44.20 & -153 & 82.27 & 21.46 & -60.81 & -283 \\
\hline $\mathrm{Mn}$ & $\mathrm{g} \mathrm{ha}^{-1} \mathrm{yr}^{-1}$ & 47.02 & 4.63 & -42.38 & -915 & 49.12 & 6.89 & -42.23 & -613 \\
\hline $\mathrm{Ni}$ & $\mathrm{g} \mathrm{ha}^{-1} \mathrm{yr}^{-1}$ & 13.85 & 3.50 & -10.35 & -296 & 15.79 & 5.07 & -10.72 & -211 \\
\hline $\mathrm{Sr}$ & $\mathrm{g} \mathrm{ha}^{-1} \mathrm{yr}^{-1}$ & 17.92 & 342.41 & 324.49 & 95 & 27.57 & 587.92 & 560.34 & 95 \\
\hline $\mathrm{Zn}$ & $\mathrm{g} \mathrm{ha}^{-1} \mathrm{yr}^{-1}$ & 253.81 & 32.14 & -221.66 & -690 & 654.19 & 40.63 & -613.57 & -1510 \\
\hline
\end{tabular}

catchment either due to solubility controls (e.g. the trace metals which precipitate in the alkaline water encountered in the aquifer and the river) or to biological uptake and sorption onto sediments (e.g. SRP species and $\mathrm{NH}_{4}$ ). The relative extent of uptake broadly divides into four groups with increasing order Fe/SRP/Organic$\mathrm{N} / \mathrm{Al} / \mathrm{Ni} / \mathrm{DHP}, \mathrm{Mn} / \mathrm{PP}, \mathrm{Co} / \mathrm{Zn} / \mathrm{Cr}$ and $\mathrm{NH}_{4}$.

\section{DRY DEPOSITION OF NITROGEN SPECIES}

Table 6 shows a comparison of the dry and wet input fluxes for oxidised and reduced nitrogen. Dry deposition has been calculated by a deposition velocity approach, using $2 \mathrm{~mm}$ $\mathrm{s}^{-1}$ for oxidised $\mathrm{N}$ and $10 \mathrm{~mm} \mathrm{~s}^{-1}$ for reduced $\mathrm{N}$ (Smith et al., 2000): similar estimates are found from regional modelling as estimated by CEH Edinburgh (for moorland in the Compton area grid, the deposition is 8.3 and $23.1 \mathrm{~kg}$ 
Table 6. Estimated concentrations of $\mathrm{NO}_{2}$ and $\mathrm{NH}_{3}$ in rainfall and wet and dry deposition to the catchments

\begin{tabular}{|c|c|c|c|c|c|c|c|c|}
\hline \multirow[t]{2}{*}{ Site } & \multicolumn{2}{|c|}{$\begin{array}{l}\text { Concentrations } \\
\left(\mu \mathrm{g} \mathrm{m}^{-3}\right)\end{array}$} & \multicolumn{2}{|c|}{$\begin{array}{l}\text { Dry deposition } \\
\left(\mathrm{kgN} h \mathrm{a}^{-1} y r^{-1}\right)\end{array}$} & \multicolumn{2}{|c|}{$\begin{array}{l}\text { Wet deposition } \\
\left(\mathrm{kgN} h a^{-1} y r^{-1}\right)\end{array}$} & \multicolumn{2}{|c|}{$\begin{array}{l}\text { Total deposition } \\
\left(\mathrm{kgN} h \mathrm{~h}^{-1} y r^{-1}\right)\end{array}$} \\
\hline & $\mathrm{NO}_{2}$ & $\mathrm{NH}_{3}$ & $\mathrm{NO}_{2}$ & $\mathrm{NH}_{3}$ & $\mathrm{NO}_{3}^{-}$ & $\mathrm{NH}_{4}^{+}$ & $\mathrm{NO}_{3}^{-}$ & $\mathrm{NH}_{4}^{+}$ \\
\hline Frilsham & 20.0 & 21.8 & 3.8 & 21.8 & 2.7 & 3.4 & 6.5 & 25.2 \\
\hline Warren Farm & 16.8 & 19.1 & 3.2 & 19.1 & 3.7 & 4.9 & 6.9 & 24.0 \\
\hline
\end{tabular}

$\mathrm{N} \mathrm{ha}^{-1} \mathrm{yr}^{-1}$ for $\mathrm{NO}_{\mathrm{x}}$ and $\mathrm{NH}_{3}$ respectively). The input of reduced nitrogen is dominated by the dry deposition component, whereas the wet and dry deposition of oxidised $\mathrm{N}$ is about equal. There may be other, non-measured dry deposition components, nitric acid vapour in particular. These input fluxes compare with inorganic $\mathrm{N}$ outputs of 8.8 and $17.0 \mathrm{~kg} \mathrm{~N} \mathrm{ha} \mathrm{kr}^{-1}$ for the Pang and Lambourn respectively (Table 5) - in other words the catchments are apparently retaining on average $50 \%$ or more of the atmospheric $\mathrm{N}$ inputs. Given that there are $\mathrm{N}$ fertiliser inputs as well, there must either be a large terrestrial/riverine sink for nitrogen or it is being lost to groundwater from which it may eventually emerge after a time delay.

Dry deposition of ammonia especially is likely to be spatially very variable, and two sampling sites are not adequate to estimate deposition over such large areas. The deposition velocities used are appropriate for low vegetation - deposition to forests would be about three times greater for the same concentration of ammonia. Forests also increase the dry deposition of sulphur dioxide and particulates, and the extent of capture is very variable (Neal et al., 1994; Robson et al., 1994): estimates of non marine sulphate deposition by $\mathrm{CEH}$ Edinburgh for moorland in the Compton area grid is $24.5 \mathrm{~kg} \mathrm{SO}_{4} \mathrm{ha}^{-1} \mathrm{yr}^{-1}$. Better site specific estimates of dry deposition to the catchment will require a combination of more measurements with modelling the response of deposition to spatial variation in the physical environment. Spatial variation in wet deposition is also important as mentioned above. Clearly a network of sites is required to determine both the wet and the dry deposition.

\section{Discussion}

This study shows that the rainfall in this rural/agricultural area is not 'clean' as it contains both nutrient and trace element contaminants and the findings are enlightening in relation to issues of catchment hydrochemistry and catchment balances, and for management purposes in relation to the nutrients $\mathrm{N}$ and $\mathrm{P}$.

For rainfall, the water quality is variable in relation to types of input (sea salts and pollutants), volume of catch and location. The atmospheric fluxes to the two catchments studied are thus hard to pin down. Further, for $\mathrm{NO}_{3}, \mathrm{NH}_{4}$, there are large gaseous deposition terms which are hard to quantify with current information. The same is probably true for $\mathrm{SO}_{4}$ where perhaps a half of the input may come from dry deposition.

Input-output relationships show some expected relationships, which take three forms:

1. There is the dominance of the major weathering products from catchment sources ( $\mathrm{Ca}, \mathrm{Sr}$ and bicarbonate).

2. There are mixed sources of inputs linked with catchment sources tied in to (a) within-catchment weathering processes $(\mathrm{Mg}$ and $\mathrm{Ba})$; (b) agricultural runoff $\left(\mathrm{NO}_{3}\right.$ and $\mathrm{K})$; and (c) point sources $(\mathrm{B}, \mathrm{Na}$, and $\mathrm{Cl})$.

3. There is the large removal of atmospheric inputs of trace transitional metals and $\mathrm{NH}_{4}$. In the case of the transition metals, they will be retained within the catchment because of the relatively high $\mathrm{pH}$ encountered within the catchment as solubility controls become operative. For $\mathrm{NH}_{4}$ uptake by the vegetation and sediments will occur and there is also conversion to $\mathrm{NO}_{3}$.

However, what was not expected was that the catchments are apparently retaining phosphorus as SRP, DHP and PP and (if dry deposition is included) nitrogen. Rather, what might be expected would be a marked net export of these elements from the catchment to the river due to agricultural and sewage effluent on top of atmospheric inputs. Even ignoring the issues of $\mathrm{N}$ and $\mathrm{P}$ inputs from the atmosphere, with average riverine fluxes of about $0.2 \mathrm{~kg}-\mathrm{P} \mathrm{ha} \mathrm{yr}^{-1}$ and $9 \mathrm{~kg}-\mathrm{N} \mathrm{ha}{ }^{-1} \mathrm{yr}^{-1}$ for $\mathrm{P}$ and $\mathrm{N}$ respectively, the agricultural inputs seem to much larger, with typical values for farmland of $13 \mathrm{~kg}-\mathrm{P} \mathrm{ha}{ }^{-1} \mathrm{yr}^{-1}$ (Leinweber et al., 2002) and $250 \mathrm{~kg}-\mathrm{N}$ $\mathrm{ha}^{-1} \mathrm{yr}^{-1}$ (Hatch et al., 2002) for $\mathrm{P}$ and $\mathrm{N}$, respectively. There are several alternatives, or some combination of these alternatives, to explain these features:

1. The catchments are strong sinks for $\mathrm{NH}_{4}, \mathrm{NO}_{3}$ and SRP. This is a distinct possibility as

a. They are essential nutrients for plant growth.

b. $\mathrm{NH}_{4}$ and SRP are strongly sorbed to the soils: SRP is 
also sorbed onto the riverine sediments.

c. There is long-term aquifer storage (for the agricultural sources at least) and this will facilitate within-aquifer degradation and in the case of SRP, inclusion into calcite lattices.

2. Atmospheric inputs are overestimated or misjudged. This might well be the case in that the increasing concentrations with lower volumes of catch, coupled with the spatial variability in rainfall chemistry may mean that there are localised sources such as insect capture by the funnel. This is observed for Warren Farm where determinand concentrations are generally higher than at Frilsham Meadow. Insect inputs are probably particularly important for SRP, DHP and PP where normally none of these $\mathrm{P}$ species would be considered as a significant term: the presence of organic $\mathrm{N}$ (and also organic P as DHP) indicates such biological inputs. However, dust inputs (wind driven and also from movement of livestock) and general agricultural practices (e.g. fertiliser applications with associated aerosol sprays) may also be important as there are local farming activities going on near the monitoring sites. Whether or not some of these inputs should be considered as contamination or 'true' atmospheric inputs remains debatable. However, further consideration of this aspect is clearly needed and the agricultural input may well be dominant.

3. The riverine and groundwater exports are underestimated. For the river, the lack of detailed storm events may result in an underestimate of flux as it is at these times when agricultural sources of $\mathrm{N}$ and $\mathrm{P}$ might be expected. In the case of the groundwater there are issues of the hydrological closure of the catchments.

4. There are issues of residence storage times with inputs from both the atmosphere and from agriculture, aquifer storage and riverine discharges that have changed and are changing with time.

5. SRP can be removed from the groundwater areas by co-precipitation with calcite (Neal, 2001; Jarvie et al., 2002a,b).

6. There are additional export terms for $\mathrm{N}$ and $\mathrm{P}$. In particular, there is the issue of the export of harvested crops and farm animals (Hatch et al., 2002; Leinweber et al., 2002).

This work provides a starting point within the LOCAR programme in respect of water quality, giving an important backdrop for separating out atmospheric from withincatchment sources. This is important for example in trying to type groundwater inputs from different parts of the aquifer using base cation data in relation to near surface sources.
For example, the rainfall data provides 'endmember' chemistries for use in two/multi-component mixing studies such as End Member Mixing Analysis (EMMA: Christophersen et al., 1990). Further, the B data provide important information for assessing human effluent sources as there are important issues of the significance of septic tank and sewage treatment work effluent inputs for SRP to the catchment/river. Such information is of particular importance for the management of riverine ecology as $\mathrm{P}$ is often the limiting nutrient. This links to the issues of whether agriculture or sewage provides the major source of SRP to the rivers at critical times of plant/algae growth.

This study highlights concerns over what is actually being collected and whether or not the rainfall flux estimates contain a significant term for 'catchment cycling' — in other words, the rainfall fluxes are derived partly from sources within the catchments and are thus not genuine inputs. Such concerns are particularly acute for nitrogen and phosphorus species. The concerns link to issues of insect and particulate matter redistributions of nutrients across catchments and/ or between catchments and there is a need to consider more fully across-catchment insect and particulate nutrient vectors of flux. The study also underlines the potential importance of gaseous deposition for $\mathrm{SO}_{4}, \mathrm{NO}_{3}$ and $\mathrm{NH}_{4}$ from both local sources and sources further afield. Clearly, there are significant unknowns/uncertainties with regard to the net input output flux and a much wider flux inventory approach is required than the one given here. This issue is of importance to the environmental management for many lowland UK catchments with regard to the nutrients. More attention, therefore, needs to be given in future research in the environmental nutrients field of rural/agricultural sustainability to (a) assessing the significance of atmospheric sources, (b) the role of farming in the distribution of local inputs and outputs of nutrients within catchments and (c) the relative importance of treated sewage as direct inputs to the river and as indirect near-river supplies (e.g. from septic tanks and animal slurry storage).

\section{References}

APHA-AWWA-WPCF, 1980. Automated Phenate Method, 417 F. Standard Methods for the examination of water and wastewater. $15^{\text {th }}$ edition. Amer. Pub. Health Ass., 1015, Fifteenth Street NW, Washington, DC, 20005, USA. 363-368.

Atkins, D.H.F., Sandalls, J., Law, D.V., Hough, A.M. and Stevenson, K.J.,1986. The measurement of nitrogen dioxide in the outdoor environment using passive diffusion tube samplers. AERE-R12133, HMSO. London, UK.

Bradford, R.B., 2002. Controls on the discharge of Chalk streams in the Berkshire Downs, UK. Sci. Total Envir., 282-283, 65-80.

Bush, A., Mooney, D. and Loader, A., 2000. UK Nitrogen Dioxide Diffusion Tube Network Instruction Manual, AEAT Report 3675 v.1.4, AEA Technology, Culham, UK. 
Cave, R.R., Ledoux, L., Turner, K., Jickells, T., Andrews, J.E. and Davies, H., 2003. The Humber Catchment and its Coastal Area: from UK to European perspectives. Sci. Total Envir., 314316, 31-52.

Christophersen, N., Neal, C., Hooper, R.P., Vogt, R.D. and Andersen, S., 1990. Modelling streamwater chemistry as a mixture of end-members - a step towards second-generation acidification models. J. Hydrol., 116, 307-320.

Drever, J.I., 2002. The geochemistry of natural waters. Prentice Hall, Upper Saddle River, NJ, USA, 436pp.

Eisenreich, S.J.M., Bannerman, R.T. and Armstrong, D.E., 1975. A simplified phosphorus analysis method. Environ. Lett., 9, 4353.

Hatch, D., Goulding, K. and Murphy, D., 2002. Nitrogen. In: Agriculture, Hydrology and Water Quality, P.M.Haygarth and S.C.Jarvis (Eds.), CABI Publishing, Wallingford, UK. 7-28.

IH, 1998. Hydrological data UK: Hydrometric Register and Statistics, 1991-95. Institute of Hydrology (now Centre for Ecology and Hydrology, Wallingford) and British Geological Survey report, Institute of Hydrology, Maclean Building, Crowmarsh Gifford, Wallingford, OXON, OX10 8BB, UK. $207 \mathrm{pp}$.

Jarvie, H.P., Neal, C. and Tappin, A.D., 1997. European landbased pollutant loads to the North Sea: an analysis of the Paris Commission data and review of monitoring strategies. Sci. Total Envir., 194/195, 41-58.

Jarvie, H.P., Whitton, B.A. and Neal, C., 1998. Nitrogen and phosphorus in east coast UK rivers: speciation, sources and biological significance. Sci. Tot. Envir, 210/211, 79-109.

Jarvie, H.P., Neal, C., Williams, R.J., Neal, M., Wickham, H., Hill, L. K., Wade, A.J., Warwick, A. and White, J., 2002a. Phosphorus sources, speciation and dynamics in a lowland eutrophic Chalk river; the River Kennet, UK. Sci. Total Envir., 282/283, 175-203.

Jarvie, H.P., Neal, C., Warwick, A., White, J., Neal, M., Wickham, H., Hill, L.K. and Andrews, M.C., 2002b. Phosphorus uptake into algal biofilms in a lowland chalk river. Sci. Total Envir., 282/283, 353-373.

Johnes, P.J., 1996. Evaluation and management of the impact of land use change on the nitrogen and phosphorus load delivered to surface waters: the export coefficient modelling approach. $J$. Hydrol., 183, 232-349.

Leeks, G.J.L. and Jarvie, H.P., 1998. Introduction to the Land Ocean Interaction Study (LOIS): Rationale and international context. Sci. Total Envir., 210/211, 5-20.

Leinweber, P., Turner, B.L. and Meissner, 2002. Phosphorus. In: Agriculture, Hydrology and Water Quality, P.M. Haygarth and S.C.Jarvis (Eds.), CABI Publishing, Wallingford, UK. 29-56.

Mainstone, C.P. and Parr, W., 2002. Phosphorus in rivers - ecology and management. Sci. Total Envir., 282-283, 25-48.

Marker, A.F.H., 1994. Chlorophyll a, SCA method revision. Report to the National Rivers Authority, PR395/3/A. 64pp.

Marsh, T.J. and Sanderson, F.J., 1997. A review of hydrological conditions throughout to period of the LOIS monitoring programme - considered within the context of the recent UK climatic instability. Sci. Total Envir, 194/195, 59-70.

Murphy, J and Riley, J.P., 1962. A modified single solution method for the determination of phosphate in natural waters. Anal. Chim. Acta, 27, 31-36.

Neal, C., 2001. The potential for phosphorus pollution remediation by calcite precipitation in UK freshwaters. Hydrol. Earth Syst. Sci. 5, 49-58.

Neal, C., Ryland, G.P., Conway, T., Jeffery, H.A., Neal, M., Robson, A.J., Smith, C.J., Walls, J. and Bhardwaj, C.L. 1994. Interception of chemicals at a forest edge for a rural low-lying site at Black Wood, Hampshire, Southern England. Sci. Total Envir., 142, 127-141.
Neal, C., Neal, M., Wickham, H. and Harrow, M., 2000a. The water quality of a tributary of the Thames, the Pang, southern England. Sci. Total Envir., 251/252, 459-476.

Neal, C., Neal, M. and Wickham, H., 2000b. Phosphate measurement in natural waters: two examples of analytical problems associated with silica interference using phosphomolybdic acid methodologies. Sci. Total Envir., 251/ 252, 513-524.

Neal, C., Jarvie, H.P., Wade, A.J. and Whitehead, P.G., $2002 \mathrm{a}$. Water quality functioning of lowland permeable catchments: inferences from an intensive study of the River Kennet and upper River Thames. Sci. Total Envir., 282-283, 259-270.

Neal, C., Jarvie, H.P., Williams, R.J., Neal, M., Wickham, H. and Hill, L., 2002b. Phosphorus-calcium carbonate saturation relationships in a lowland chalk river impacted by sewage inputs and phosphorus remediation: an assessment of phosphorus selfcleansing mechanisms in natural waters. Sci. Total Envir., 282/ 283, 295-310.

Neal, C., Leeks, G.J.L., Millward, G.E., Harris, J.R.W., Huthnance, J.M.and Rees, J.G., 2003. Land Ocean Interaction: processes, functioning and Environmental management: aspective. Sci. Total Envir., 314-316, 801-820.

Neal, C., Jarvie, H.P., Wade, A.J., Neal, M., Wyatt, R., Wickham, H., Hill, L. and Hewitt, N., 2004. The water quality of the LOCAR Pang and Lambourn catchments. Hydrol. Earth Syst. Sci., 8, 614-635.

Owens, M., Headworth, H.G. and Morgan-Jone, M., 1991. Groundwater in basin management. In: Applied Groundwater Hydrology, R.A. Downing and W.B.Wilkinson, (Eds.), 16-34.

Robson, A.J. and Neal, C., 1997. A summary of regional water quality for Eastern U.K. rivers. Sci. Total Envir., 194/195, 1537.

Robson, A.J., Neal, C., Ryland, G.P. and Harrow, M., 1994. Spatial variations in throughfall chemistry at the small plot scale. $J$. Hydrol., 158, 107-122.

Smith, R.I., Cape, N., Binnie, J., Murray, T.P., Young, M. and Fowler, D., 1997. Deposition of atmospheric pollutants to the LOIS area. Sci. Total Envir., 194/195, 71-85.

Smith, R.I., Fowler, D., Sutton, M.A., Flechard, C. and Coyle, M., 2000. Regional estimation of pollutant gas dry deposition in the UK: model description, sensitivity analyses and outputs. Atmos. Environ., 34, 3757-3777.

Sutton M.A., Miners B., Tang Y.S., Milford C., Wyers G.P., Duyzer J.H. and Fowler D., 2001. Comparison of low-cost measurement techniques for long-term monitoring of atmospheric ammonia. J. Environ. Monit. 3, 446-453.

Truesdale, V.W. and Smith, C.J., 1976. The automatic determination of silicate in natural freshwater by means of procedures involving the use of either alpha or beta molybdosilicic acid. Analyst, 101, 19-31.

Vincent, K.J., Cambell, G.W., Downing, C.E.H., Hasler, S.E., Davies, M., Stedman, J.R., Sansom, L.E., Briscombe, C. and Page, H.M., 1996. Acid Deposition in the United Kingdom: the first 10 years. AEA Technology pls, National Environment Centre, E1 Culham, Abingdon, OXON, OX14 3DB, UK, 32pp plus 3 appendices.

Whitehead, P.G., Johnes, P.J. and Butterfield, D., 2002. Steady state and dynamic modelling of nitrogen in the River Kennet: impacts of land use change since the 1930s. Sci. Total Envir., 282/283, 417-434.

Withers, P.J.A. and Lord, E.I. 2002. Agricultural nutrient inputs to rivers and groundwaters in the UK: policy, environmental management and research needs. Sci. Total Envir., 282-283, 924. 